\title{
Commentary: Which place could the radial artery take in coronary artery bypass grafting?
}

\author{
Bastien Provost, MD, ${ }^{\mathrm{a}, \mathrm{b}}$ Kevin Pluchon, MD, ${ }^{\mathrm{a}, \mathrm{b}}$ and Eric Bezon, MD ${ }^{\mathrm{a}, \mathrm{b}, \mathrm{c}}$
}

\footnotetext{
From the ${ }^{\mathrm{a}}$ Department of Cardiovascular and Thoracic Surgery, Brest University Hospital, Brest, France; ${ }^{\mathrm{b}}$ European University of Brittany, Brest, France; and ${ }^{c}$ Faculty of Medicine, University of Brest, Brest, France. Disclosures: Authors have nothing to disclose with regard to commercial support.

Received for publication Nov 1, 2018; accepted for publication Nov 1, 2018; available ahead of print Dec 19, 2018.

Address for reprints: Eric Bezon, MD, Service de Chirurgie Cardiaque, Thoracique et Vasculaire, CHU la Cavale Blanche, Brest 29609 Cedex, France (E-mail: eric.bezon@ chu-brest.fr).

J Thorac Cardiovasc Surg 2019;158:453-4

$0022-5223 / \$ 36.00$

Copyright (C) 2018 by The American Association for Thoracic Surgery

https://doi.org/10.1016/j.jtcvs.2018.11.005
}

Coronary artery bypass grafting with a bilateral internal thoracic artery (ITA) produces better outcomes than the use of a single ITA. ${ }^{1}$ The ideal of total arterial revascularization has been based on the presumption that all arterial grafts are associated with superior long-term patency compared with saphenous vein (SV) grafts, but radial artery (RA) grafts are unlikely to approach the patency of ITA grafts. The results of this study confirm that. Multiple arterial revascularizations using the 2 ITAs give better 10-year results than multiple arterial revascularizations using the left ITA added to an RA. Also, the authors used complex statistical methods to show the higher patency of RA versus $\mathrm{SV}$ grafts as few randomized controlled trials and metaanalysis have ever shown. ${ }^{2,3}$

The main limit of this study apart from the short followup of the bilateral ITA group is the lack of strategy advised by the authors for using RA grafting. The results of this study could lead us to use the RA instead of the SV graft. Unfortunately, the authors stopped performing multiple arterial revascularization using the left ITA added to an RA in 2010. Moreover, in the bilateral ITA group, they have used the RA 3 times less frequently than the SV graft. This study cannot help us to specify the place of RA grafting.

The benefits of bilateral ITA grafting (Figure 1) did not become evident until after 10 years; thus, bilateral ITAs are most appropriate in patients surviving longer. The patency of the RA graft is strictly lower than the right ITA graft. More than 10 years would be necessary to notice the benefits of the RA over the SV added to left ITA grafting. Is there a benefit in elderly patients to use an RA instead of an SV added to the left ITA? The use of RA grafts could be associated with a lower incidence of myocardial infarction and repeat revascularization without an impact on longterm mortality. ${ }^{4}$

Could we use an RA graft instead of the right ITA graft in younger patients? The RA could be an alternative conduit in patients at risk for postoperative sternal complications, but

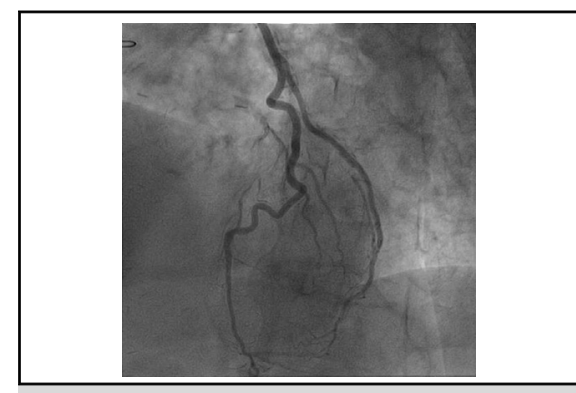

Ten-year follow-up angiography: revascularization of the left-sided coronary vessels with bilateral ITA.

\section{Central Message}

An ITA graft is better than an RA graft, which is better than an SV graft.

See Article page 442.

the incidence decreased when the skeletonized harvesting technique was used. Last but not least, the RA probably will be used to graft the right coronary artery when the bilateral ITA has been used to graft the left coronary system. Conflicting data on the results of RA grafting of the right coronary artery are probably due to unobserved

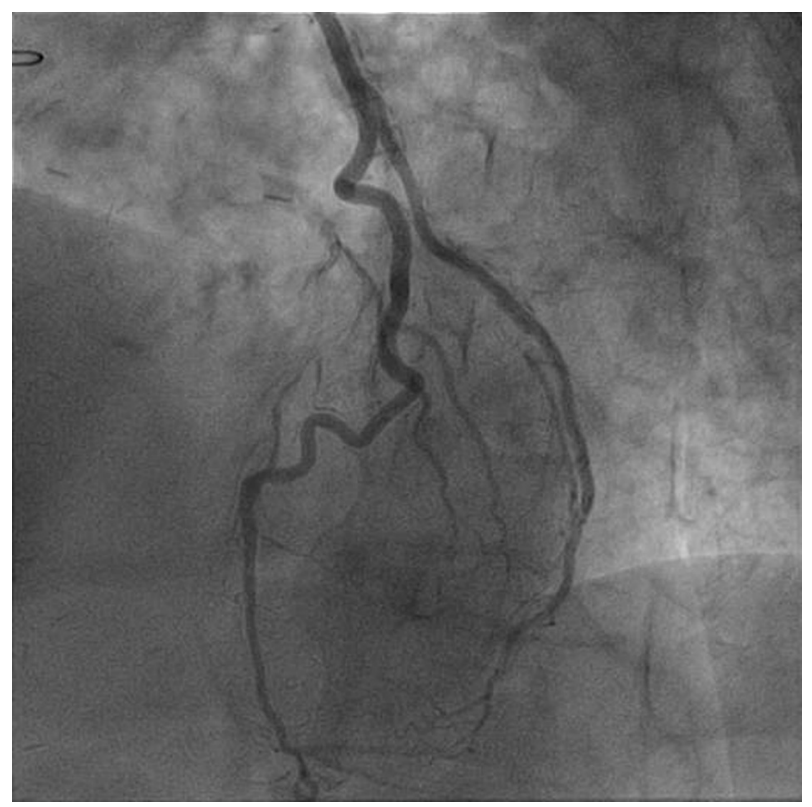

FIGURE 1. Ten-year follow-up angiography: revascularization of the left-sided coronary vessels with bilateral ITA. 
preoperative variables. ${ }^{5-7}$ In case of a bilateral ITA graft of the left coronary system, an occlusion of the right coronary artery graft does not have the same impact on the long-term results if the native lesion of the right coronary artery is a proximal stenosis, a distal stenosis or a stenosis of its terminal branches, or an occluded artery distally perfused from the left coronary system. Further studies must take this variable into account to specify when surgeons must perform RA grafting of the right coronary artery.

\section{References}

1. Locker C, Schaff HV, Daly RC, Dearani JA, Bell MR, Frye RL, et al. Multiple arterial grafts improve survival with coronary artery bypass graft surgery versus conventional coronary artery bypass grafting compared with percutaneous coronary interventions. J Thorac Cardiovasc Surg. 2016;152:369-79.

2. Deb S, Cohen EA, Singh SK, Une D, Laupacis A, Fremes SE, et al. Radial artery and saphenous vein patency more than 5 years after coronary artery bypass sur- gery: results from RAPS (radial artery patency study). J Am Coll Cardiol. 2012; 60:28-35.

3. Cao C, Manganas C, Horton M, Bannon P, Munkholm-Larsen S, Ang SC, et al. Angiographic outcomes of radial artery versus saphenous vein in coronary artery bypass graft surgery: a meta-analysis of randomized controlled trials. J Thorac Cardiovasc Surg. 2013;146:255-61.

4. Gaudino M, Benedetto U, Fremes S, Biondi-Zoccai G, Sedrakyan A, Puskas JD, et al; RADIAL Investigators. Radial-artery or saphenousvein grafts in coronary-artery bypass surgery. N Engl J Med. 2018;378: 2069-77.

5. Athanasiou T, Ashrafian H, Mukherjee D, Harling L, Okabayashi K. Are arterial grafts superior to vein grafts for revascularisation of the right coronary system? A systematic review. Heart. 2013;99:835-42.

6. Shia WY, Tatoulisb J, Newcomb AE, Rosaliona A, Fullerd JA, Buxton BF. Is a third arterial conduit necessary? Comparison of the radial artery and saphenous vein in patients receiving bilateral internal thoracic arteries for triple vessel coronary disease. Eur J Cardiothorac Surg. 2016;50:53-60.

7. Pinho-Gomes AC, Azevedo L, Antoniades C, Taggart DP. Comparison of graft patency following coronary artery bypass grafting in the left versus the right coronary artery systems: a systematic review and meta-analysis. Eur J Cardiothorac Surg. 2018;54:221-8. 